\title{
Development of the Technology of Poultry Litter Treatment into Organic Fertilizer through Its Decontamination by the Low-Temperature Pyrolysis Method
}

\author{
R. L. Isemin, A. V. Mikhalev, O. Y. Milovanov, L. V. Stepantsova, and V. A. Solopov
}

\begin{abstract}
Dry poultry waste can be used as a valuable fertilizer for seedbed preparation and spring fertilizing of winter crops. One of the major limitations for the direct application of organic waste in the soil is the presence of conditionally pathogenic and pathogenic microorganisms, preserving viability and virulence for a long time. The low-temperature pyrolysis of pelleted litter mass at $250^{\circ} \mathrm{C}$ and treatment time of $60 \mathrm{~min}$. allows for complete decontamination of this type of waste. Reducing the pyrolysis temperature to $155^{\circ} \mathrm{C}$ even when the treatment time was $60 \mathrm{~min}$. did not fully decontaminate the litter mass. There was also a series of experiments on the use of pelleted litter mass subjected to low-temperature pyrolysis for 1 hour at $250{ }^{\circ} \mathrm{C}$ as a fertilizer. It was found that by introducing these pellets into the soil in an amount of 2 tons/ha, the barley yield increased by $16.2 \%$; the timing of fruit formation of the tomato variety "Krasavets" reduced from 70 to 62 days from the start of germination, and the starting date of ripening decreased from 95 to 82 days; the yield of "Santana" potato variety increased by $36.5 \%$ up to 62 tons/ha.
\end{abstract}

Index Terms-Organic fertilizer, pathogenic organisms, poultry litter, pyrolysis.

\section{INTRODUCTION}

Currently, many poultry farms in different regions of Russia are facing a dangerous environmental situation caused by the lack of appropriate technologies to ensure an environmentally safe treatment of poultry litter for its subsequent use as an organic fertilizer to improve the fertility of soil.

The Russian poultry farms produce 10 million tons of litter and litter mass annually. These wastes are not disposed of properly, which leads to significant economic and environmental damage. Thus, according to the estimates of the Ministry of Agriculture of Russia, agricultural companies' payments for placing of litter and other wastes on their grounds reach 35 billion Russian rubles per year, not including fines for environmental pollution.

Manuscript received December 5, 2016; revised March 25, 2017. This work was supported in part by the Ministry of Education and Science of the Russian Federation (Contract \# 02.G25.31.0185).

R. L. Isemin and A. V. Mikhalev are with the Tambov State Technical University, Tambov, Sovetskaya st., 106, Russia (e-mail: penergy@ list.ru).

O. Y. Milovanov is with the Clean Energy, Tambov, Michurinskaya st., 112 I, Russia (e-mail: penergy@ list.ru).

L. V. Stepantsova and V. A. Solopov are with the Michurinsk State Agrarian University, Michurinsk, Internationalnaya st. 101, Russia (e-mail: solopov@mgau.ru).

\section{STATEMENT OF THE PROBlem}

Dry poultry waste can be used as a valuable fertilizer for seedbed preparation and spring fertilizing of winter crops. The amount of available nitrogen, phosphorus and potassium reaches $100 \%, 70 \%$ and $90 \%$, respectively. The fertilizer contains a complete set of microelements, sufficient quantities of humic and folic acids, and their salts. The fertilizer enhances photosynthesis, which is the main process used by plants.

One of the major limitations for the direct application of organic waste in the soil is the presence of conditionally pathogenic and pathogenic microorganisms, preserving viability and virulence for a long time. When the poultry litter containing pathogenic microorganisms is introduced into the soil, they are inactivated only after a certain period of time [1], but this period can be sufficient for pathogenesis before achieving an environmentally sound balance.

Microbiological analysis showed that poultry litter contained microscopic fungi Fusarium genera, Aspergillus, Penicillium [2], [3]. Most of the Fusarium-fungi are phytotrophs. They affect different families of plants, causing a variety of pathological phenomena and open the way for the invasion of the so-called "sugar fungi", which quickly use the available carbohydrates (sugar, starch). This group of fungi includes Aspergillus, Penicillium characterized by rapid growth, capable of capturing large areas in a short time. These fungi are among the strongest toxin formers in the soil and organic substrates. Therefore, the presence of Fusarium, Aspergillus, Penicillium fungi in an organic fertilizer makes it unsuitable for use in most cultivated crops.

Thus, the poultry litter is a source of soil contamination with pathogens in the area adjacent to the outdoor litter storage.

Decontamination of litter is carried out by biothermal, chemical, thermal and physical methods.

Currently, there are two most important biotechnological approaches to recycling of organic substance from litter: exothermic fermentation or composting for production of humus substrate, and anaerobic digestion for production of biogas [4]. The main disadvantages of both processes are a long duration (up to 90 days) and a significant loss of organic matter and nutrients (50\%). In addition, composting leas to the formation of a great amount of conditioned plant pathogens in the resulting compost, the toxicity of which is often manifested in the delay of seed germination.

Drying of poultry litter in drum-type facilities with direct-flow and counter-flow of raw materials and of coolant is energy consuming and does not guarantee a complete 
disinfection of the litter. The litter samples were obtained after drying in a drum dryer at a temperature of incoming gas of $800-1000^{\circ} \mathrm{C}$, the temperature of exhaust gases was $120-140{ }^{\circ} \mathrm{C}$ and the holding time was at least 30 minutes. These samples contained coliform bacteria, staph bacteria and the total molecular number of colony forming units was greater than $500,000 / \mathrm{g}$.

Litter disposal by burning, including burning together with coal [5], as well as pyrolysis of poultry litter [6] leads to virtually complete elimination of this valuable fertilizer, results in a significant emission of ash, dust and nitrogen oxides and requires a considerable amount of energy due to the high moisture content of raw litter.

Thus, the development of energy-efficient and low-cost technology of litter decontamination for production of granulated organic fertilizer is relevant.

\section{PROBLEM SOLVING}

Disposal of all kinds of poultry litter involves its recycling into organic fertilizer under the following conditions: 1) the full and guaranteed decontamination of litter, 2) preservation of the maximum amount of organic substance, 3) minimization of energy and time spent on decontamination of litter.

These conditions are satisfied in the case of treatment of the original poultry litter by the low-temperature pyrolysis.

The low-temperature pyrolysis is a process of heat treatment of biomass at temperatures not exceeding $300{ }^{\circ} \mathrm{C}$ in a low oxygen content. This kind of treatment causes a substantial removal of moisture and oxygen from the biomass and a slight removal of hydrogen [7]-[9].

The low-temperature pyrolysis of litter and its mixtures as the energy technological process has been insufficiently investigated [10]. The possibility of using the low-temperature pyrolysis as a litter decontamination technology for the subsequent use of the resulting product as a fertilizer has never been studied.

Filling those gaps is the aim of the present work.

\section{METHODS AND EQUIPMENT}

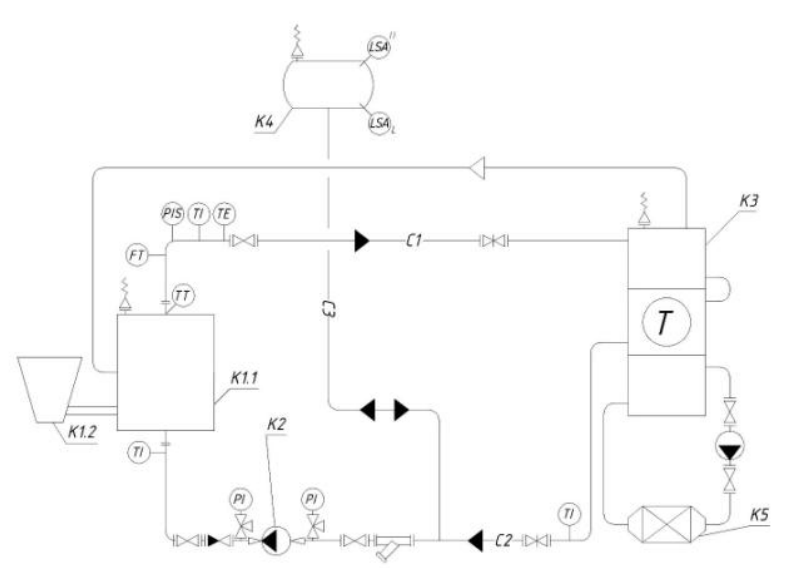

K1.1 - boiler, K1.2 - litter loading unit for decontamination, K2 circulation pump, $\mathrm{K} 3$ - litter pyrolysis reactor, $\mathrm{K} 4$ - expansion tank, K5 cooling system for decontaminated pellets, including the waste heat disposal system.

Fig. 1. The experimental setup for low-temperature pyrolysis of poultry litter.
Fig. 1 shows the experimental setup designed to study the low-temperature pyrolysis of litter.

The reactor for low temperature pyrolysis litter is shown in Fig. 2. The reactor consists of three sections with horizontal trays used to transport the material from one tray to another, i.e. from the loading point to the unloading point, by using a twin-blade agitator. The reactor has a jacket heated by high-temperature oil. The lower section of the rector is cooled by water through the jacket and the tray, which makes it possible to obtain a product with a temperature, which excludes its ignition in the air at the reactor outlet. The duration of the pyrolysis can be controlled. Gases released in the pyrolysis are directed to the furnace, where they are burned. Valves installed between the reactor sections exclude spontaneous entering of biomass from one section to another.

As can be seen from the reactor diagram, the inert gas is fed into the two upper section. However, if the moisture content of the treated biomass is high enough, as experience shows, feeding of the inert gas is not necessary.

The reactor is operated as follows. The heat transfer medium at a temperature of $230-260^{\circ} \mathrm{C}$ is fed in to the reactor jacket (two upper sections) and into the jacked of two upper trays. The cooling water is fed into the lower section of the reactor (reactor jacket and jacket trays).

After the high-temperature heat transfer medium is fed into the reactor, the heating of the internal volume of the reactor begins. After the temperature inside the reactor reaches $220^{\circ}$ $\mathrm{C}$, the litter in an amount of 20 to $160 \mathrm{~kg}$ is loaded in the upper section of the reactor. After the litter is loaded, the temperature begins to rise due to the contact with the hot walls of the reactor. At the same time, the moisture and volatile substances leave the litter through its layer, which contributes to the rapid heating of the upper layers of the litter.

In the pyrolysis the reactor agitator rotates at $0.8 \mathrm{rev} . / \mathrm{min}$. The residence time of the litter in the upper sections of the reactor may vary, but the total time of the thermal treatment must be at least 30 minutes.

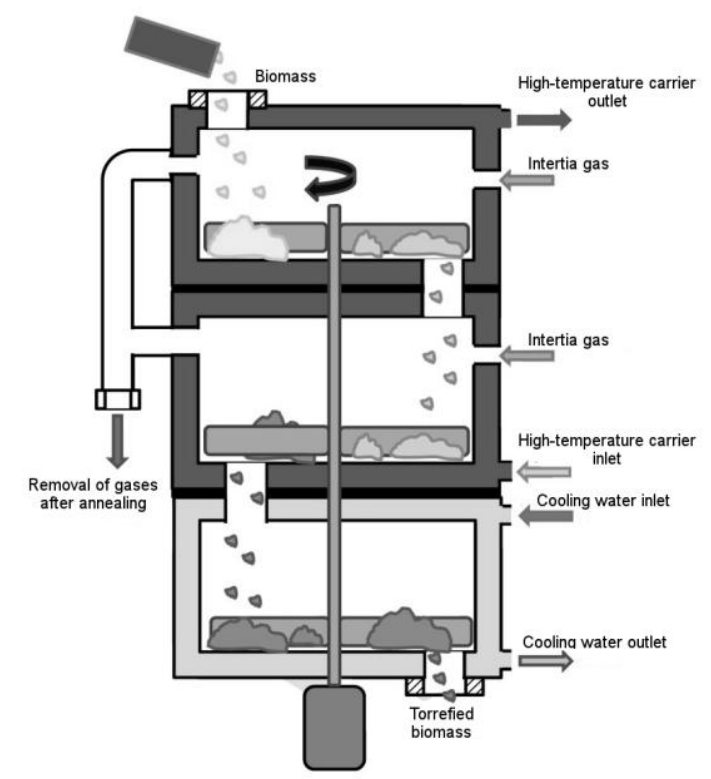

Fig. 2. The reactor diagram for litter pyrolysis.

The thermometer controls the temperature, with the values shown on the remote system control. 
The total residence time of litter in the heat treatment zone should not exceed 2 hours at the initial moisture content of biomass of at least $10 \%$.

The low-temperature pyrolysis of the litter mass was conducted experiments for the following parameters:

For the raw litter mass treated at $250^{\circ} \mathrm{C}$, the treatment time was $60 \mathrm{~min}$.

For the pelleted litter mass treated at a temperature of $155^{\circ}$ $\mathrm{C}$, the treatment time was $30 \mathrm{~min} ., 45 \mathrm{~min}$. and $60 \mathrm{~min}$.

For the pelleted litter mass treated at a temperature of $250^{\circ}$ $\mathrm{C}$, the treatment time was $60 \mathrm{~min} ., 45 \mathrm{~min}$. and $60 \mathrm{~min}$.

In the experiments we studied the process of low-temperature pyrolysis of the raw litter mass and pelleted mass, supplied by the Company 'Inzhavinskaya Poultry Plant "(the Tambov region) and OOO" Vefa - Green" (the Leningrad region). Physical and chemical characteristics of the litter mass samples were found using standard methods.

For the investigated litter decontamination technology, it is important to reduce the frequency of testing of microorganisms in the organic fertilizer after treatment. Particular attention should be given to this indicator in relation to pathogenic organisms: Fusarium, Cladosporium, Penicillium and Aspergillus. The frequency of testing of microorganisms was determined by direct seeding of weighed portion (1g) of test samples into solid nutrient medium.

The total microbial count is an important indicator for assessing the general microbiota. This is one of the key indicators defined in the sanitary and microbiological studies. It is a total number of microorganisms in a sample unit. Its value is expressed as colony forming units (CFU). It is assumed that the higher the CFU is, the higher is the amount of pathogens in the test sample. The amount of CFU correlates with the degree of contamination.

According to [11], the CFU was measured by suspension seeding method (10 gram sample in $100 \mathrm{ml}$ water) in the raw litter mass samples subjected to a low temperature pyrolysis at the process parameters mentioned above. A weighed portion of the sample was triturated with $10-15 \mathrm{ml}$ of sterile water, and then the water volume was increased to $100 \mathrm{ml}$. From the resulting aqueous suspension 6-7 serial dilutions (1:10) were prepared. The last two dilutions were used for seeding on nutrient medium. Petri dishes were incubated at $25^{\circ} \mathrm{C}$ for two days. The calculation of colonies was carried out in the samples, in which the number of colonies did not exceed 300 . The microorganism colonies were recalculated per $1 \mathrm{~g}$ of substrate.

\section{RESULTS AND DISCUSSION}

Raw litter mass has wide fractional composition of the pieces up to $100-150 \mathrm{~mm}$ and a particle size of 1 to $3 \mathrm{~mm}$. Pelleted litter mass is a pellets of $8 \mathrm{~mm}$ in diameter and average length of $12 \mathrm{~mm}$

Physical and chemical characteristics of untreated litter mass are shown in Table I. As can be seen from Table I, despite the fact that the litter mass samples were supplied from poultry farms remote from each other at a distance of over $1000 \mathrm{~km}$, their physical and chemical characteristics were quite similar, suggesting the applicability of the results presented here for other poultry farms.
TABLE I: CHARACTERISTICS OF UNTREATED LITTER MASS

\begin{tabular}{|c|c|c|}
\hline Indicator & Raw litter mass & Pelleted litter mass \\
\hline Moisture content, w\% & 10.92 & 8.27 \\
\hline Ash content & 13.97 & 12.58 \\
\hline $\begin{array}{l}\mathrm{pH} \text { (one percent aqueous } \\
\text { solution), } \mathrm{w} \%\end{array}$ & 7.12 & 6.82 \\
\hline $\mathrm{C}$ org. (general), w\% & 33.9 & 36.6 \\
\hline C org. (water-soluble), w\% & 6.6 & 5.7 \\
\hline $\mathrm{N}$ (general), w\% & 8.43 & 7.5 \\
\hline $\mathrm{N}$ (water-soluble), w\% & 0.88 & 2.24 \\
\hline $\mathrm{NO}_{3}, \mathrm{mg} / \mathrm{kg}$ & 958 & 0 \\
\hline $\mathrm{SiO}_{2}, \mathrm{w} \%$ & 1.59 & 1.55 \\
\hline $\mathrm{P}_{2} \mathrm{O}_{5}, \mathrm{w} \%$ & 2.98 & 2.58 \\
\hline $\mathrm{K}_{2} \mathrm{O}, \mathrm{w} \%$ & 3.01 & 2.06 \\
\hline $\mathrm{Na}_{2} \mathrm{O}, \mathrm{w} \%$ & 0.27 & 0.4 \\
\hline $\mathrm{CaO}, \mathrm{w} \%$ & 0.71 & 0.75 \\
\hline $\begin{array}{l}\text { Content of water-soluble } \\
\text { salts, w\% }\end{array}$ & 4.59 & 5.78 \\
\hline \multicolumn{3}{|c|}{ Water-soluble compounds } \\
\hline $\mathrm{Na}_{2} \mathrm{O}$ (water-soluble), w\% & 0.27 & 0.4 \\
\hline $\mathrm{CaO}$ (water-soluble), w\%. & 0 & 0 \\
\hline $\mathrm{MgO}$ (water-soluble), w\% & 1.41 & 1.53 \\
\hline $\mathrm{K}_{2} \mathrm{O}$ (water-soluble), w\% & 2.91 & 1.51 \\
\hline $\mathrm{P}_{2} \mathrm{O}_{5}$ (water-soluble), w\% & 0.337 & 0.414 \\
\hline $\mathrm{Cl}$ (water-soluble), w\% & 1.2 & 2.06 \\
\hline $\mathrm{HCO}_{3}, w \%$ & 4.34 & 4.27 \\
\hline $\mathrm{SO}_{4}$ (water-soluble), w\% & 0 & 0 \\
\hline
\end{tabular}

TABLE II: THE CONTENT OF PATHOGENIC ORGANISMS IN THE RAW LITTER

\begin{tabular}{|l|l|l|}
\hline Microorganism & $\begin{array}{l}\text { Raw litter } \\
\text { mass }\end{array}$ & $\begin{array}{l}\text { Pelleted } \\
\text { litter mass }\end{array}$ \\
\hline Mucor (colonies) & 1.0 & 1.0 \\
\hline Penicillium (colonies) & 2.5 & 1.6 \\
\hline Aspergillus (colonies) & 1.8 & 0.3 \\
\hline Cladosporium (colonies) & 6.5 & 0 \\
\hline Fusarium (colonies) & 0.2 & 0 \\
\hline Trichoderma (colonies) & 0.67 & 1 \\
\hline Bacterial microbiota & 0.55 & 0 \\
\hline Average number of colonies & 1.88 & 0.56 \\
\hline CFU in 1g of weighted portion & $9.4 \times 10^{5}$ & $2.8 \times 10^{5}$ \\
\hline
\end{tabular}

Table II shows data on the content of pathogenic organisms in the raw litter mass.

As shown in Table II, pelleting of litter mass with heating in the press to $110^{\circ} \mathrm{C}$ can significantly reduce the content of pathogenic microorganisms, but it cannot completely decontaminate the litter mass.

Table III presents the results of microbiological analysis of the litter mass by the low-temperature pyrolysis.

Table III. The content of pathogenic organisms in the litter mass after the low-temperature pyrolysis.

The analysis of the data presented in Table III shows that the low-temperature pyrolysis of pelleted litter mass at $250^{\circ} \mathrm{C}$ and treatment time of $60 \mathrm{~min}$. allows for complete decontamination of this type of waste. Reducing the pyrolysis temperature to $155^{\circ} \mathrm{C}$ even when the treatment time was 60 min. did not fully decontaminate the litter mass.

The raw litter mass was not fully decontaminated by the low-temperature pyrolysis at $250^{\circ} \mathrm{C}$ and treatment time of 1 hour. This can be explained by the fact that varying particle size composition of the raw litter mass prevented the uniformity of treatment by pyrolysis. On the other hand, as 
noted above, that the process of litter mass pelleting ensures only partial decontamination, however, it is quite sufficient.

Thus, the decontamination process of the litter mass comprises two stages: Stage 1 - pelletizing of the litter mass, Stage 2 - low-temperature pyrolysis of the pellets at $250^{\circ} \mathrm{C}$ for 60 minutes.

TABLE III: THE CONTENT OF PATHOGENIC ORGANISMS IN THE LITTER MASS AFTER THE LOW-TEMPERATURE PYROLYSIS

\begin{tabular}{|c|c|c|c|c|c|}
\hline \multirow{2}{*}{ Microorganism } & Raw litter mass & \multicolumn{4}{|c|}{ Pelleted litter mass } \\
\cline { 2 - 6 } & \multicolumn{3}{|c|}{ Low-temperature pyrolysis parameters } \\
\cline { 2 - 6 } & $\begin{array}{c}250{ }^{\circ} \mathrm{C} \\
60 \mathrm{~min}\end{array}$ & $\begin{array}{c}155^{\circ} \mathrm{C} \\
30 \mathrm{~min} .\end{array}$ & $\begin{array}{c}155^{\circ} \mathrm{C} .45 \\
\mathrm{~min} .\end{array}$ & $\begin{array}{c}155^{\circ} \mathrm{C} . \\
60 \mathrm{~min} .\end{array}$ & $\begin{array}{c}250^{\circ} \mathrm{C} . \\
60 \mathrm{~min} .\end{array}$ \\
\hline Aspergillus (colonies) & 1.0 & 0.33 & 0.84 & 0.5 & 0 \\
\hline Cladosporium (colonies) & 1.6 & 0 & 2.0 & 1.2 & 0 \\
\hline Fusarium (colonies) & 0 & 0.5 & 0.2 & 0.3 & 0 \\
\hline Trichoderma (colonies) & 1.7 & 5.5 & 1.3 & 0.2 & 0 \\
\hline Bacterial microbiota & 0 & 0.2 & 0 & 0 & 0 \\
\hline Average number of colonies & 0.5 & 1.0 & 0.67 & 0 & 0 \\
\hline CFU in 1g of weighted portion & 0.33 & 0.5 & 0.17 & 0 & 0 \\
\hline
\end{tabular}

The findings of the physical and chemical analysis of the treated pellets showed that after the treatment the moisture content reduced by 1.79 times, the ash content increased by 1.38 times, $\mathrm{pH}$ was 6.76 , the carbon content (total) increased by 1.07 times, the soluble carbon content decreased by 3.8 times, the nitrogen content increased by 1.17 times, the soluble nitrogen content decreased by 3.34times, the $\mathrm{SiO} 2$ content increased by 1.41 times, the $\mathrm{P} 2 \mathrm{O} 5$ content increased by 1.44 times, the $\mathrm{K} 2 \mathrm{O}$ content increased by 1.33 times, the $\mathrm{Na} 2 \mathrm{O}$ content increased by 1.3 times, the $\mathrm{CaO}$ content increased by 1.3 times, the water-soluble salts content decreased by 1.2 times.

The low-temperature pyrolysis of pelleted litter mass at $250^{\circ} \mathrm{C}$ reduced the moisture content by 1.79 times and ensured the hydrophobicity of pellets, thus reducing the risk of secondary infection, even when exposed to the contact with the environment during transportation.

The pyrolysis performed at a temperature of $250^{\circ} \mathrm{C}$ caused partial decarbonization. As a result, the acidity of litter mass reduced to values close to neutral ( $\mathrm{pH}$ was 6.2-6.8), which are the most favorable for plant growth. This fact is confirmed by the reduction of $\mathrm{HCO}_{3}$ content by 1.83 times in the aqueous extract of the sample after the pyrolysis.

The total nitrogen content in the raw material was $8-9 \%$, $10-12 \%$ of which was readily degradable in water-soluble form. The presence of nitrates in raw materials indicates the development of microbiological processes caused by the action-nitrifying bacteria. The pyrolysis at $2500 \mathrm{C}$ led to a drastic reduction of the content of water-soluble easily decomposed forms of nitrogen (by 3.34 times) and the absence of unpleasant odor in the samples.

After the pyrolysis at a temperature of $2500 \mathrm{C}$ the ash content in the final product increased to $18-20 \%$. Accordingly, the share of the mineral components increased. At the same time, the potassium mobility slightly decreased $(70-80 \%$ of bulk content went in the aqueous solution compared to $100 \%$ in the raw material), and the phosphorus mobility increased (the content of water-soluble forms increased to $0.6 \%$ ). It should be noted that the ratio of nitrogen - phosphorus potassium due to the loss of a certain amount of nitrogen became more balanced (respectively 8 - 4 - 3).

There was also a series of experiments on the use of pelleted litter mass subjected to low-temperature pyrolysis for 1 hour at $250^{\circ} \mathrm{C}$ as a fertilizer.

It was found that by introducing these pellets into the soil in an amount of 2 tons/ha, the barley yield increased by $16.2 \%$; the timing of fruit formation of the tomato variety "Krasavets" reduced from 70 to 62 days from the start of germination, and the starting date of ripening decreased from 95 to 82 days; the yield of "Santana" potato variety increased by $36.5 \%$ up to 62 tons/ha.

\section{CONCLUSION}

The studies suggest that pelleting of the litter mass followed by low-temperature pyrolysis allow for expedited treatment of this waste into a fully decontaminated organic fertilizer.

The optimal low-temperature pyrolysis process parameters are a temperature of $250^{\circ} \mathrm{C}$ and the treatment time of 1 hour.

\section{REFERENCES}

[1] V. A. Sedyh, Z. Norovsuran, and A. V. Filippov, "Osobennosti ispol'zovanija ptich'ego pometa pri primenenii $\mathrm{v}$ agrocenozah [Features of using poultry litter in agrocenoses]," Izvestija Orenburgskogo gosudarstvennogo agrarnogo universiteta, issue 32-1, vol. 4. pp. 283-286, 2011.

[2] L. E. Matrosova, "Obezvrezhivanie ptich'ego pometa mikromicetami [Decontamination of poultry litter by micromycetes]," Uchenye zapiski kazanskoj gosudarstvennoj akademii veterinarnoj mediciny im. N.Je. Baumana, vol. 211, pp. 95-98, 2012.

[3] R. J. Andreev, "Sanitarno-bakteriologicheskoe sostojanie pochvy, zagrjaznennoj organicheskimi othodami zhivotnovodstva [Sanitary bacteriological condition of soil contaminated with organic animal waste]," // Veterinarnyj vrach, vol. 2, pp. 26-27, 2011.

[4] B. P. Kelleher, J. J. Leahy, A. M. Henihan, T. F. O’Dwyer, D. Sutton, and M. J. Leahy, "Advances in poultry litter disposal technology - a review," Bioresource Technology, vol. 83, pp. 27-36, 2002.

[5] L. Jiaand and E. J. Anthony, "Combustion of poultry - derived fuel in a CFBC," International Conferenceon Fluidized Bed Combustion, X'ian, China, 2009.

[6] D. Vamvuka, S. Sfakiotakis, and K. D. Panopoulos, "An experimental study on the thermal valorization of municipal and animal wastes," International Journal of Energy and Environment, vol. 4, issue 2, pp. 191-198, 2013.

[7] J. J. Chew and V. Doshi, "Recent advances in biomass pretreatment Torrefaction fundamentals and Technology," Renewable and Sustainable Energy Reviews, vol. 15, pp. 4212-4222, 2011.

[8] D. R. Nhuchhen, P. Basu, and B. A. Acharya, "Comprehensive Review on Biomass Torrefaction," International Journal of Renewable Energy \& Biofuels, 2014.

[9] B. Acharya, I. Sule, and A. Dutta, "A review on advances of torrefaction technologies for biomass processing," Biomass Conversion and Biorefinery, vol. 2, pp. 349-369, 2012.

[10] A. Dhungana, "Torrefaction of biomass," Master of Applied Science at Dalhousie University Halifax, Nova Scotia, August 2011.

[11] Pravila bakteriologicheskogo issledovanija kormov. [Regulations of feed bacteriological research]. Approved by the General Directorate Veterinary Ministry of Agriculture of the USSR, June 10, 1975. 


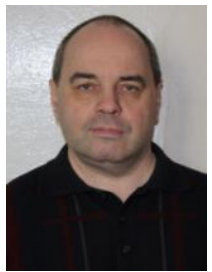

Rafail Isemin was born in Tambov, Russia in 1959. He earned his engineer diploma at Tambov Institute of Chemical Engineering, Tambov, Russia in 1981. He earned his Ph.D. degree at Lomonosov Moscow State Academy of Fine Chemical Technology, Tambov, Russia in 1993.

He is currently a principal reseacher at Tambov State Technical University, Tambov, Russia. His current combustion and torrefaction. research interests include heat systems, fluidized bed

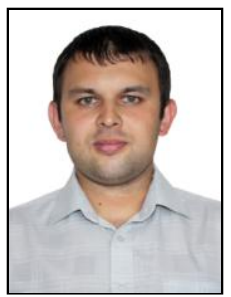

Alexander Mikhalev was born in Tambov state, Russia in 1979. He earned his engineer diploma at Tambov State Technical University, Tambov, Russia in 2001. He earned his Ph.D. degree at Tambov State Technical University, Tambov, Russia in 2007.

He is currently a senior reseacher at Tambov State Technical University, Tambov, Russia. His current research interests include heat systems, fluidized bed combustion and torrefaction.

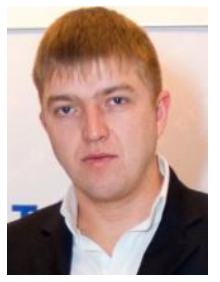

Oleg Milovanov was born in Tambov, Russia in 1987 He earned his Bachelor of Engineering at Tambov State Technical University, Tambov, Russia in 2009 and his Master of Engineering in 2011. He earned his Ph.D. degree at Tambov State Technical University, Tambov, Russia in 2016.

He is currently a research engineer at Clean Energy, spin-off company of Tambov State Technical University, Tambov, Russia. His current research interests include heat systems, fluidized bed combustion and torrefaction.

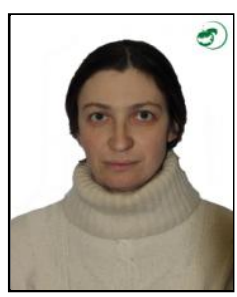

Ludmila Stepantsova was born in Yaroslavl state, Russia in 1972. She earned her engineering diploma at Moscow Geological Prospecting Academy n. a. Sergo Ordzhonikidze, Moscow, Russia in 1995. She earned her Ph.D. degree at Lomonosov Moscow State University, Moscow, Russia in 2002. She earned her Doctor of Biological Sciences degree at Lomonosov Moscow State University, Moscow, Russia in 2012.

She is currently a professor of Michurinsk State Agrarian University, Michurinsk, Russia. Her current research interests include agrochemistry and edaphology.

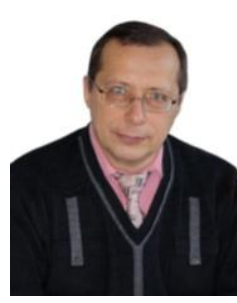

Vladimir Solopov earned his degree in economics at Michurinsk State Agrarian University, Michurinsk, Russia in 1981. He earned his Ph.D. degree at Research Institute of agricultural Economics, Moscow, Russia in 1989. He earned his Doctor of Economic Sciences Doctor degree at Michurinsk State Agrarian University, Michurinsk, Russia.

$\mathrm{He}$ is currently the vice-rector for Science of Michurinsk State Agrarian University, Michurinsk, Russia. His current research interests include agri-food market and the agricultural marketing. 